\title{
AKTIVITAS ANTIOKSIDAN EKSTRAK AIR DAUN JAMBU MAWAR (Syzygium Jambos Alston) METODE PERENDAMAN RADIKAL BEBAS DENGAN DPPH
}

\author{
Herson Cahaya Himawan ${ }^{1 *}$, Inawati ${ }^{2}$, Anisah Lubis ${ }^{3}$ \\ 1. . Program Studi Farmasi Sekolah Tinggi Teknologi lndustri dan Farmasi Bogor \\ 2 Pmgram Studi Farmasi Sekolah Tinggi Teknologi lndustri dan Farrnasi Bogor \\ 3. Muhasiswa Program Studi D3 Farmasi Sekolah Tinggi Teknologi lndustri dan Farmasi Bogor \\ Korespondensi: hersonindonesia2011@gmail.com
}

\begin{abstract}
ABSTRAK
Penuaan dan penyakit degeneratif seperti kanker, katarak, penurunan sistem kekebalan tubuh, dan disfungsi otak terjadi kaerna adanya kerusakan sel yang disebabkan oleh radikal bebas. Radikal bebas merupakan molekul atau atom tidak stabil. Antioksidan adalah zat yang dapat melindungi sel dari kerusakan yang disebabkan oleh radikal bebas. Tanainan merupakan salah satu sumber antioksidan alami, salah satu turnbuhan yang memiliki aktivitas antioksidan yaitu Daun jambu mawar ( Syzygium Jambos Alton ). Daun jambu mawar merupakan tanaman yang memiliki aktivitas antioksidan dan dapat digunakan sebagai alternatif dalam pengobatan. Tujuan dari penelitian ini adalah untuk menentukan aktivitas antioksidan daun jambu mawar menggunakan metode peredaman radikal bebas dengan DPPH. Ekstrak air daun jambu mawar dibuat deret konsentrasi 20, 40, 60, 80 dan 100 ppm, dilarutkan dengan metanol dan DPPH, kernudian diukur absorbansinya menggunakan Spektrofotorneter UV- vi.s pada panjang gelombang 515,5 $\mathrm{nm}$. Ekstrak air daun jambu mawar mempunyai nilai IC $_{50}$ sebesar 85,514 ppm. Kesimpulan penelitian ini bahwa aktivitas antioksidan ekstrak air daun jambu mawar memiliki aktivitas antioksidan dan termasuk kategori kuat.
\end{abstract}

Kata kunci: Antioksidan, DPPH, Ekstrak air, daun jambu mawar

\begin{abstract}
Aging and degenerative diseases such as cancer, cataracts, decreased immune system, and brain dysfunction occur due to cell damage caused by free radicals. Free radicals are unstable molecules or atoms. Antioxidants are substances that can protect cells from damage caused by free radicals. Plants are a source of natural antioxidants, one of the plants that have antioxidant activity, namely rose guas'a leaf (Syzygium Jambos Alston). Rose guava leaf are plants that have antioxidant activ'ity and can be used as an alternative in medicine. The purpose of this study was to determine the antioxidant activity of rose guas'a leaf using the free radical scavenging method with DPPH. The water extract of rose guav'a leaf was made with a concentration series of 20, 40, 60, 80 and 100 ppm, dissolved with methanol and DPPH, then the absorbance was measured using a UV -vis spectrophotometer at a wavelength of $515.5 \mathrm{~nm}$. The water extract of guava lea〉'es has an 1C< value of $88.814 \mathrm{ppm}$. The conclusion of t his study is that the antioxidant actis'ity of rose guava leaf water extract has antioxidant activity and is in the strong category.
\end{abstract}

Keywords: Antioxidants, DPPH, water extract, rose guava leaf 


\section{PENDAHULUAN}

Senyawa radikal bebas dalam kehidupan sehari hari tidak dapat kita pisahkan. Makanan yang dibakar atau digoreng, terpaan sinar matahari, asap kendaraan, , racun, obat obatan tertentu, cemaran udara adalah penyebab terbentuknya senyawa radikal bebas. Elektron-elektron yang tidak berpasangan dari suatu senyawa dapat menimbukan radikal. Senyawa radikal bebas ini akan mengikat electron molekul sel tubuh.[1]

Senyawa reaktif disebabkan karena adanya electron yang tidak mempunyai pasangan dikulit terluar disebut radikal bebas [2] Substansi yang dibutuhkan tubuh untuk meredam radikal bebas dan menghindari kerusakan yang diakibatkan oleh senyawa tersebut dengan melengkapi elektron tidak berpasangan tersebut disebut senyawa antioksidan.[3]Dengan mengisolasi dan mensintesis bagian tumbuhan antioksidan dapat diperoleh. Yang terkenal adalah BHT dan BHA. Namun saat ini penggunaan senyawa tersebut karena mempunyai sifat karsinogen [4] Oleh sebab itu perlu di cari alternative lain yaitu antioksidan alami yang berasal dari bahan alam.. Salah satu tumbuhan yang mempunyai senyawa-senyawa aktif antioksidan ialah jambu mawar (.Svzvprum jomho. alston).. Kulit batang dan buah syzygium jambos mengandung flavonoid, saponin dan tannin, polifenol terkandung dalam daun dan buahnya 15].Berdasarkan penelitian [6] daun jambu mawar Syzygium Jambos positif mengandung fenol, flavonoid, dan steroid atau triterpenoid. Berdasarkan Devi Adityahastutik (2019) ekstrak etanol $70 \%$ daun jambu mawar dikategorikan antioksidan sangat kuat dengan nilai $\mathrm{IC}_{50} 27,83$ ppm mempunyai aktivitas antioksidan yang sangat kuat karena dalam range $<50 \mathrm{ppm}$. Oleh sebab itu perlu penelitian antioksidan yang bertujuan untuk mencari tahu aktivitas antioksidan dari ekstrak air daun jambu mawar.

\section{METODE PENELITIAN}

Bahan Daun jambu mawar yang didapat dari kotamadya Bogor Desa C iapus, aquadest, metanol, DPPH (diphenylpicrylhidrazyl), vitamin C, pereaksi mayer, pereaksi wagner, preaksi dragendoff, asam sulfat pekat, klorofom, asam asetat anhidrat, $\mathrm{FeCl} 3$.
Alat beaker glass, pipet tetes, tabung reaksi, labu takar, spirtus, kasa besi, spatel, pipet volume, termoneter, batang pengaduk, tiinbangan elektrik, spektrofotoineter Uv'v'is.

\section{Metode}

\section{Pembuatan Simplisia Daun Jambu Mawar}

Pengumpulan bahan baku daun jambu mawar yang digunakan adalah daun segar sebanyak $3 \mathrm{~kg}$ yang didapat dari desa ciapus. Keinudian daun disortasi basah. untuk meinisahkan kotoran-kotoran dari bahan simplisia, setelah itu dilakukan pencucian kotoran pada simplisia dan tanah, kemudian dilakukan pengeringan haksel 24 jam dengan cara diangin-anginkan agar air dari daun berkurang, kemudian bahan simplisia dirajang untuk mempercepat pengeringan, selanjutnya bahan simplisia dikeringkan agar sirnplisia yang tidak cepat rusak, kemudian dilakukan sortasi kering untuk mernisahkan benda asing atau kotoran yang tidak diinginkan, kemudian dil aku kan penghalusan menggunakan blender, selain itu dilakukan pengayakan agar lebih halus menggunakan ayakan 40 mesh, simplisia yang didapat dari hasil pengayakan adalah sebanyak 300 gram, simplisia yang sudah diayak disimpan dalam botol bewarna gelap dan diberi silica gel yaitu agar simplisia tidak lembab, kemudian diberi etiket agar tidak tertukar dengan simplisia lainya.

\section{Penetapan Kadar Air}

Metode gravimetric digunakan dalam penetapan kadar air, dan dilakukan pada temperature $105 \mathrm{C}$ selama 30menit cawan porselin dipanaskan dalam oven, lalu didinginkan dalam desikator sampai dingin dan ditimbang. Serbuk simplisia jambu mawar ditimbang sebanyak $5 \mathrm{~g}$ keinudian diletakkan dalam cawan porselin dan dipanaskan di oven pada temperature 105 "C dalam waktu lebih kurang 3 jam. Setelah di oven cawan porselin yang berisi sampel didinginkan dalam desikator dan ditimbang bobotnya, dilakukan berulang kali sampai diperoleh bobot konstan dengan selisih I mg. Syarat umum untuk kadar air daun, yaitu $<10 \%$.

Persen kadar air masing-masing serbuk daun jambu mawar dapat dihitung dengan rumus :

$$
\begin{aligned}
& \% \quad \text { Kadar } \quad \text { Air } \\
& \frac{\text { Bobot Sampel Awal }(\mathrm{g})-\text { Bobot Sampel Akhir }(\mathrm{g})}{\text { Bobot Sampel Awal }(\mathrm{g})} \times 100 \%
\end{aligned}
$$




\section{1) Ekstraksi}

Serbuk simplisia daun jambu mawar sejumlah 10 gram diletakkan ke dalam 100 $\mathrm{ml}$ aquadest, kemudian dipanaskan selama 15 menit mulai $90^{\circ} \mathrm{C}$ diatas penangas air menggunakan termometer sambil sesekali diaduk. Saat isi infusa ber kurang aquadest panas ditambahkan secukupnya melalui ampas hingga diperoleh volume infusa 100 $\mathrm{ml}$ kemudian hasil infusa dipekatkan menggunakan waterbath,ditunggu hingga menyusut.

Ekstrak yang telah diperoleh kemudian dihitung rendcmennya dengan umus berikut :

$\%$ Rendemen $=\frac{\text { Bobot Ekstrak }(\mathrm{g})}{\text { Bobot Serbuk Simplisia }(\mathrm{g})} \times 100 \%$

\section{Uji Fitokimia Daun Jambu Mawar [7]}

a. Alkaloid

Beberapa $\mathrm{ml}$ ekstrak, ditambahkan $2 \mathrm{ml}$ $\mathrm{CHCL}_{3}$ serta $2 \mathrm{ml}$ ainoniak kemudian disaring. Filtrat selanjutnya ditambahkan 3-5 tetes asam sulfat pekat kemudian digoyang goyangkan sampai terjadi dua lapisan. Ketabung reaksi lain sejumlah 3 tabung bagian atas dipindahkan masing-masing 2,5 ml. Ketiga larutan dalam tabung tersebut ini dianalisis dengan pereaksi Wagner,Mayer dan Dragendorff sejumlah 4-5 tetes. Endapan yang terbentuk menunjukkan alkaloid ada dalam sampel tersebut. Endapan putih akan terbentuk jika bereaksi dengan Mayer, endapan merah jingga akan terbentuk jika bereaksi dengan Dragendorff dan endapan coklat akan terbentuk jika bereaksi dengan Wagner.

b. Flavonoid

Ekstrak cair sebanyak $5 \mathrm{ml}$ ditambahkan logam $\mathrm{Mg} \quad 0.5 \mathrm{mg}$, kemudian ditetesi dengan asam klorida pekat dan amilalkohol sejumlah $1 \mathrm{ml}$. Campuran selanjutnya dihornogenkan. Flavonoid ditunjukkan dengan adanya warna kuning dan merah pada lapisan amil alcohol.

c. Tanin

$5 \mathrm{ml}$ sampel ditambahkan kedalam air sampai tidak mempunyai warna, selanjutnya diambil 2 $\mathrm{ml}$ dan ditetesi I -2 tetes pereaksi $\mathrm{FeCl} 3$. Warna kehitaman hijau atau biru memperlihatkan hasil positif tanin.

d. Saponin

Ekstrak cair sebanyak $1 \mathrm{ml}$ dikocok selamna 10 detik. Apabila

muncul busa $1-10 \mathrm{~cm}$ yang stabil dalam selang waktu lebih

kurang 10 menit dan tidak hilang dengan penambahan 1 tetes asam klorida maka pada sampel terkandung adanya saponin .

e. Steroid dan Terpenoid

Sebanyak I ml ekstrak cair dilarutkan dengan air hingga $0,5 \mathrm{ml}$ klorofom kemudian ditambahkan 0,5 $\mathrm{ml} \mathrm{CH} 3 \mathrm{COOH}$ anhidrat, dan campuran ditetesi dengan $2 \mathrm{ml}$ asam sulfat pekat. Hasil yang mengandung steroid ditunjukan dengan warna hijau/biru sedangkan hasil positif yang mengandung terpenoid ditunjukan dengan adanya warna merah atau ungu.

2) Pengujian Aktivitas Antioksidan

a. Pembuatan Larutan DPPH $0,5 \mathrm{mM}$

Serbuk DPPH sejumlah $10 \mathrm{mg}$ diletakkan ke labu ukur berukuran $50 \mathrm{ml}$ kemudian ditambah metanol selanjutnya dikocok hingga larut dan selanjutnya ditambalikan metanol sampai tanda batas [8].

b. Pencarian panjang geloinbang maksinum 1arutan DPPH 0,5 M sejumlah $1 \mathrm{~mL}$ ditambahkan $4 \mathrm{ml}$ metanol p.a selanjutnya di homogenkan dan diukur absorbansinya pada rentang $510-520 \mathrm{~nm}$ menggunakan metanol blanko [8] .

c. Pembuatan Larutan yang akan diuji 1000 ppm

Larutan yang akan diuji $1.000 \mathrm{ppm}$, dibuat dengan cara menimbang 0,1 gr ekstrak daun jambu mawar, dimasukkan kelabu ukur $100 \mathrm{ml}$ dan selanjutnya akuades hingga tanda batas. dari larutan yang akan diuji tersebut dibuat konsentasi berseri sejumlah 5 konsentrasi masing masing yaitu $100 \mathrm{ppm}, 80 \mathrm{ppm}, 60$ ppm, 40 ppm dan 20 ppm

d. Pembuatan Larutan V itamin C 1000 ppm

$50 \mathrm{mg}$ serbuk $\mathrm{C}$ dilarutkan dengan aquadest dalam labu ukur $50 \mathrm{ml}$. Dari larutan ini dibuat seri konsentrasi vitamin $\mathrm{C}$ konsentrasi 6 ppm, 5 ppm, 4 ppm, 3 ppm dan 2 ppm.

e. Penentuan Nilai Absorbansi

Larutan yang akan diuji dan kontrol yang dibuat berbagai konsentrasi diambil sebanyak I ml sampel, metanol $2 \mathrm{ml}$, ditambahkan $1 \mathrm{~mL}$ DPPH dimasukkan dalam tabung reaksi kemudian digoyang goyangkan. Dibiarkan dalam waktu 0.5 jam, selanjutnya diukur absorbansinya pada lamda maksimurn. Metanol digunakan sebagai blanko dan vitamin C sebagai kontrol positif.

f. Data Analisis rumus

Persen penghambatan diukur dengan

$$
\% \text { Inhibisi }=\frac{\text { Abs Blanko }- \text { Abs Sampel }}{\text { Abs Blanko }} \times 100 \%
$$

Penjelasan

A blanko = absorbansi DPPH $0,5 \mathrm{mM}$ 
55 | Triyani Sumiati et, al., (Sintesis dan Karakterisasi Cangkang Kapsul Keras...)

A spamel $=$ absorbansi sampel terhadap radikal DPPH 0,5 mM

Kemampuan antioksidan menangkal radikal bebas DPPH infusa daun jambu mawar dan vitamin $\mathrm{C}$, dipelajari dan dihitung nilai IC 50 memakai analisis regresi linear.

$\mathrm{y}=\mathrm{a}+\mathrm{bx}$

Penjelasan :

$\mathrm{y}=\%$ aktivitas antioksidan

$\mathrm{x}=$ konsentrasi larutan yang akan diuji $\mathrm{a}=$ tetapan slope

$\mathrm{b}=$ tetapan intersep

Data absorbansi kemudian dimasukkan ke dalam persamaan regresi dengan konsentrasi ekstrak sebagai absis (sumbu $\mathrm{x}$ ) dan nilai persentase peredaman (aktivitas antioksidan) sebagai ordinatnya (sumbu y). Hasil analisis regresi linear berupa nilai $\mathrm{x}$, dimasukkan ke dalam rumus $1 \mathrm{C}=$ anti $\log \mathrm{x}$ dan ditentukan tingkat daya antioksidannya.

Tabel 1. Kategori Aktivitas Antioksidan [8]

Tingkat Kekuatan Antioksidan Dengan Metode DPPH Intensitas

Nilai IC $(\mu \mathrm{g} / \mathrm{ml})$

Sangat Kuat

Kuat

Sedang

Lemah

Sangat Lemah
$<50$

$50-100$

$100-150$

$150-200$

$>200$

\section{HASIL DAN PERIBAHASAN}

Pembuatan Simplisia Daun Jambu mawar

Daun jambu mawar yang digunakan sebanyak $3 \mathrm{~kg}$ dam didapatkan simplisiia sebanyak 30 gram pengeringan dilakukan dengan cara diangin-anginkan agar tidak mudah rusak dan dihaluskan untuk memperkecil ukuran simplisia agar semua bagi dapat terekstraksi secara menyeluruh. Simplisia serbuk daun jambu mawar bersama hijau dengan bau khas. Hasil serbuk simplisia dapat dilihat Gambar 3.

\section{Penetapan Kadar Air}

Berdasarkan penelitian kadar air yang dilakukan di Sekolah Tinggi Teknologi Industri dan Furmasi dengan menggunakan metode gravimetri dipemleh nilai kadar air dari daun jambu rnawar sebesar 7,2\%. Hal ini memenuhi syarnt ketentum kadar air untuk daun, sehingga simplisia tidak rnudah ditumbuhi jarnur maupun mikroba.

Ekstraksi

Serbuk simplisia sebanyak 10 gram

\section{Gambar 3. Serbuk Simplisia Daun Jarnbu Mawar}

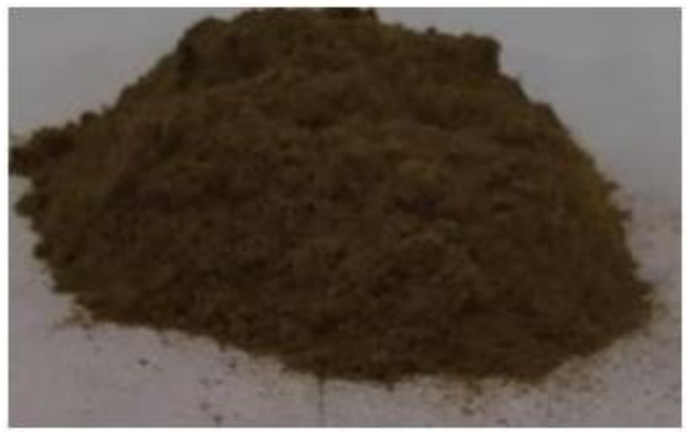

untuk di infus selama 15 menit pada suhu 90-98 C dengan akuades sebanyak $100 \mathrm{ml}$. Hasil infusa yang berupa filtrnt akan dipekatkan dengan menggunakan water bath , untuk mendapatkan ekstrak kental. Ekstrak kental yang didapat dari daun jambu mawar mempunyai warna coklat kemerahan, dengan khas daun jambu mawar.

Bobot ekstruk kental yang didapat dari daun jambu mawar sebesar 2,43 gnim 
56 | Herson Cahaya Himawan et, al., (Aktivitas Antioksidan Ekstrak Air Daun Jambu ...)

hingga didapat rendemen 24,3 \%. Hasil jambu mawar dapat dilihat pada Gambar 4. ekstrak cair dan ekstrak kental dari daun

\section{Gambar 4. Ekstrak kental Daun Jambu Mawar}

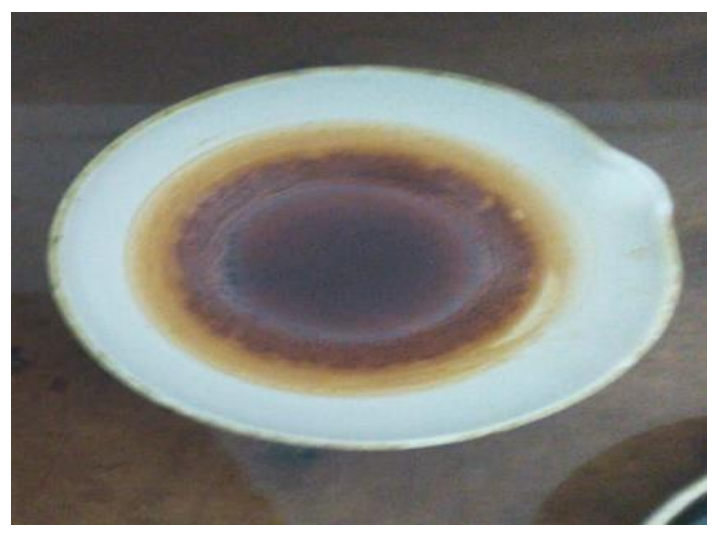

Kandungan Fitokimia Daun Jambu Mawar

Skrining fitokimia adalah suatu metode pencirian kandungan senyawa aktif secara kualitatif dengan menggunakan berbagai pereaksi untuk mendeteksi adanya kandungan senyawa metabolit sekunder yang terdapat di daun jambu mawar yang berpotensi memiliki aktititas antioksidan.
Skrining fitokimia yang dilakukan pada penelitian ini adalah identifikasi alkaloid, flavonoid, saponin, tannin, terpenoid dan steroid. Berdasarkan hasil pengujian diperoleh hasil skrining fitokimia daun jambu mawar dapat dilihat pada Tabel 2.

\begin{tabular}{clc}
\hline Golongan Senyawa & Hasil & Ekstrak Infusa \\
\hline & Alkaloid & - \\
a. Dragendorf & Tidak ada endapan & - \\
c. Wagner & b. Mayer & Endapan putih \\
Terpenoid & Tidak ada endapan & + \\
Flavonoid & Larutan berwarna merah & + \\
Saponin & Warna hijau kekuningan & + \\
Tanin & Terbentuk busa & + \\
& Larutan kehitaman &
\end{tabular}

Keterangan : $(-)=$ tidak mengandung zat aktif, $(+)=$ mengandung zat aktif

Pada uji fiitokimia ini, hasil yang didapat dari ekstrak daun jambu mawar yakni positif mengandung alkaloid mayer. Pada pembuat pereaksi Mayer, ditandai dengan terbentuknya endapan putih. Pada pengujian terpenoid menunjukkan bahwa ekstrak daun jambu mawar memberikan hasil positif karena terbentuknya cincin pada batas antara kloroform dan asam sulfat.

Hasil positif dari uji flavonoid dapat ditemukan pada ekstrak daun jambu mawar, hal ini ditandai dengan rnunculnya warna hijau kekuningan. Pada percobaan identifikasi saponin pada ekstrak air daun jambu mawar menunjukkan hasil positif ditandai dengan munculnya busa atau buih selama lebih dari 10 menit. Pada saponin, senyawa ini merupakan senyawa bentuk glukosida dan bersifat polar. Identifikasi tanin dari ekstrak air daun jambu mawar menunjukkan hasil pnsitif yang ditandai dengan perubahan warna kehitaman pada sampel.

Hasil Pengukuran Panjang Gelombang DPPH

Pengukuran panjang gelornbang ini mempunyai tujuan untuk memastikan panjang gelombang pada saat senyawa memberikan absorbunsi maksirnum dari hasil pengukuran larutan DPPH diperoleh panjang gelombang maksimum sebesar $515,5 \mathrm{~nm}$ dengan absorbunsi sebesar 0,951 . Hal ini 
57 | Herson Cahaya Himawan et, al., (Aktivitas Antioksidan Ekstrak Air Daun Jambu ...)

sesuai dengan pemyataan menurut Hartanto gelombang dapat dilihat pada Gambar 6.

(2012) bahwa elektron pada radikal bebas

DPPH memberikan penyerapan maksirnum 517

nrn dengan warna ungu grafik panjang

\section{Gambar 6. Hasil Pengukurun maksimurn Panjang Gelornang DPPH}

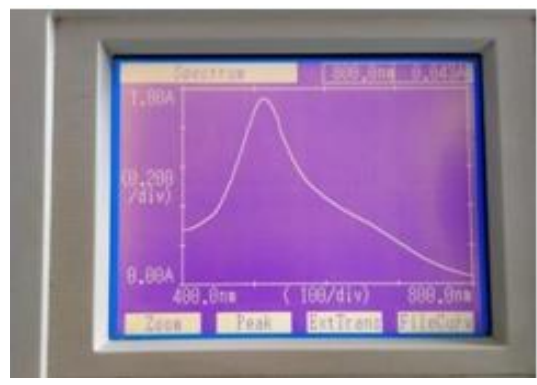

a. Spektra Absorbansi DPPH

\section{Aktivitas antioksidan ekstrak daun jambu} mawar $\begin{array}{crr}\text { Penetapan antioksidan } & \text { dengan } \\ \text { menggunakan DPPH jika dilakukan secara }\end{array}$ kualitatif dapat dilihat dari perubahan warna

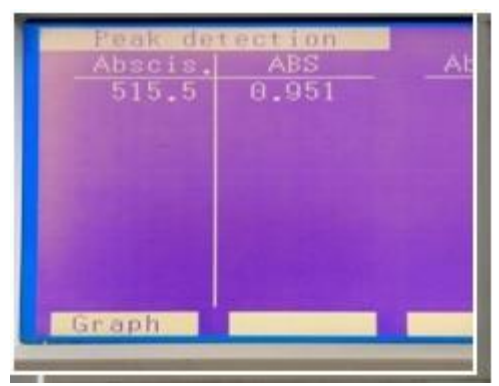

b. Absorbansi Maksimum DPPH

dari ungu menjadi kuning. Aktivitas antioksidan dan \% inhibisi seperti pada Gambar 7 dan Tabel 3.

Gambar 7. Grafik Hubungan antam konsentrusi (ppm) dan \% inhibisi Daun Jambu Mawar

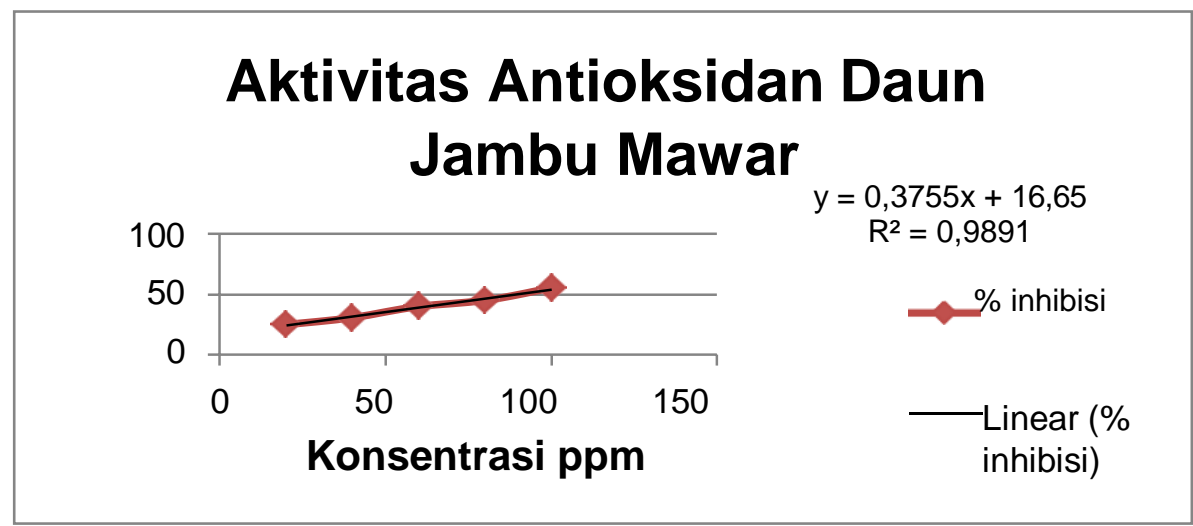

Tabel 3. Aktivitas Antioksidan Daun Jambu Mawar

\begin{tabular}{lcc}
\hline No & Konsentrasi ppm & \% Inhibisi \\
\hline 1 & 20 & 24,9 \\
2 & 40 & 30,7 \\
3 & 60 & 40 \\
4 & 80 & 45 \\
5 & 100 & 55,3 \\
\hline
\end{tabular}

Berdasarkan hasil penetapan antioksidan yang telah dilakukan ekstrak kental daun jambu mawar mempunyai nilai IC sebesar 88.14 ppm termasuk dalam kategori antioksidan yang kuat (Molyneux. 2(J(u). Hasil ini tidak lebih baik dari penelitian Devi adityahastutik (2019) dimana ekstrak etanol $96 \%$ daun jambu mawar (Syzygium jambos Alston) menggunakan metode maserasi dapat menangkal radikal bebas dan termasuk dalam golongan kategori sangat kuat dengan nilai IC sebesar $27,83 \mathrm{ppm}$. Suatu bahan dapat dikatakan aktif sebagai antioksidan apabila persentase aktivitas antioksidan lebih atau sama dengan 
58 | Herson Cahaya Himawan et, al., (Aktivitas Antioksidan Ekstrak Air Daun Jambu ...)

50\% (Parwata,2009) Nilai IC50 merupakan kisaran nilai yang menunjukkan kekuatan antioksidan suatu sampel. Semakin rendah nilai IC50 maka semakin kuat aktivitas antioksidan suatu sampel (Hidaiat, 2(J()5).

Berdasarkan Gambar 7 menunjukkan bahwa semakin tinggi konsentrasi sampel, semakin besar kemampuan sampel dalam menangkal radikal bebas. Hal ini disebabkan karena semakin banyak atom hidrogen yang didonorkan oleh senyawa metabolit sekunder pada senyawa DPPH [9] (Rahayu, 2010).

Terdapat perbedaan intensitas antioksidan atau perbedaan nilai 1C50 antara penelitian ini dengan penelitian daun air jambu mawar (Devi Adityahastutik, (2019), dapat disebabkan karena perbedaan wilayah pengarnbilan bahan sampel. Selain itu, pertumbuhan dan metabolisme tanaman dipenguruhi oleh perubahan temperatur lingkungan. Keadaan tanah, kondisi perairan. penampilan morfologi dan fisiologi tanaman serta intensitas dari rnatahari [10] .

\section{Aktivitas Antioksidan Vitamin C}

Dalam pengujian antinksidan ini digunakan control positif Vitamin $\mathrm{C}$ yang merupakan antioksidan yang baik, maka dilakukan pengujian antioksidan terhadap Vitamin $\mathrm{C}$ untuk membandingkan aktivitas antioksidan dari sampel yang diuji. Pada penelitian ini nilai IC50 dari Vitamin C sebesar 3,608 ppm dan tergolong sangat kuat ( $\mathrm{Mol}$ yneux, 2004). Data aktivitas antioksidan dan \% inhibisi seperti pada Gambar 8 dan Tabel 4.

\section{Gambar 8. Grafik Hubungan antara konsentrasi (ppm) dan \% inhibisi Vitamin C}

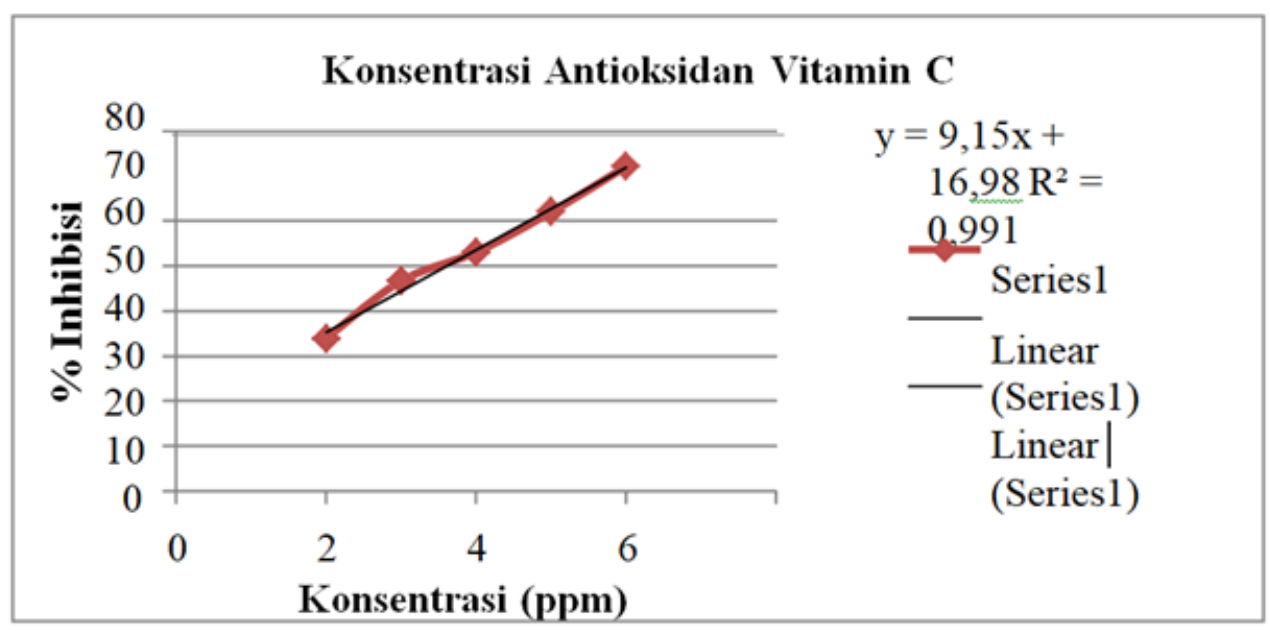

Tabel 4. Aktivitas Antioksidan Vitamin C

\begin{tabular}{lll}
\hline No $\quad$ Konsentrasi ppm & $\%$ Inhibisi \\
\hline
\end{tabular}

\begin{tabular}{ccc}
1 & 2 & 34 \\
2 & 3 & 46,7 \\
3 & 4 & 53,1 \\
4 & 5 & 62 \\
5 & 6 & 72,1 \\
\hline
\end{tabular}




\section{SIMPULAN}

Dari hasil penelitian yang telah dilakukan dapat disimpulkan bahwa:

a. Hasil penapisan fitokimia ekstrak air dari daun Jambu Mawar (Syzygium Jambos Alston) mengandung senyawa alkaloid, flavonoid. tanin, terpenoid, dan saponin.

b. Daun Jambu mawar (Syzygium Jambos Alston) mempunyai aktivitas anti oksidan yang kuat dengan IC50 88.814 ppm dan vitamin C sebagai control positif dengan IC50 sebesar 3,608 ppm.

\section{SARAN}

Saran pada Penelitian ini adalah perlu dilakukan kombinasi dengan herbal turn guna mendapatkan senyawa aktif yang diduga antioksidan dalam daun jambu mawar.

\section{DAFTAR PUSTAKA}

[1] Pietta, P-G. 1999. Flavonoid As Antioxidant, Reviews. Journal National Product, 63:1035-1042.

[2] Winarsi, H. 2007. Antioksidan Alami dan Radikal Bebas Potensi dan Aylikasinya dalam Kesehatan. Yogyakarta: Kanisius.

[3] Prakash, A., 2001 . Antioxidant Activity. Medallion Laboratories Analitycal Progrew.s. 19: 2

[4] Takashi,M.,danTakayumi,S.1997.Antioxid ant Activities of Natural Compoud Found in Plants. JAgricFood Chem. 45 :18191822.

[5] Zheng. Ni.. Zhaoyu. Wang. L-eng, chen, dan Jingming. 2011. Evaluation to The Antioxidant Activit y of Total Flavonoids
Extract From $S$ ygium jambos Seeds and Ofitimi Nation by Response Surface Methodolo gy, African Journal of Pharmacy and Pharmacolo gy Vol. 5(21), pp. 2411-2419.

[6] Devi. Aditi yhastutik. 2019. Aktivitas Antioksidan Ko rnbinasi Ekstrak Etanol 7(J*7r Daun Jambu Mawar (S5!(-)!gium jnm lan.s) dan Daun Jambu Bol $(. S)_{<, z}$ gi $\ll \mathrm{m}$ m(iinccrli.sr) dengan Metode DPPH.

[7] Harborne, J.B. 1957 Metode Fitokimia. Ter. Dari Phytochemical Method.s oleh Kosasih Pndmnwinntn dan Iwang Soediro. Penerbit ITB. Bandung: 47-245.

[8] Molyneux , P. 2004. The Use Of The Stable F-ree Radical Diphenylpicryhidrazil (DPPH) for Estimating Antioxidant Activity. Songklanakarin Journal Science Technology. 26: 211-219.

[9] Rahayu, D. S., K. Dewi, dan F- Enny , 2010. Penentuan Aktivitas Antioksidan dari Ekstrak Etanol Daun Ketapang Terminalia catafiya L.) dengan metode 1,1 difenil 2 pikrilhidrazil (DPPH). Skripsi. Semarang: Universitas Diponegoro.

[10] Fatchurrozuk, Surnnto, dan Sug iarto. 2013. Pengaiuh Ketinggian Tempat Terhadap Kandungun Vitamin $\mathrm{C}$ dan Zat Antioksidan pada Buah A<mirzi /uifıc.srrn.s di Dataran Tinggi Dieng. $E L$ VIVCt. 1 (1) : 24-31. 